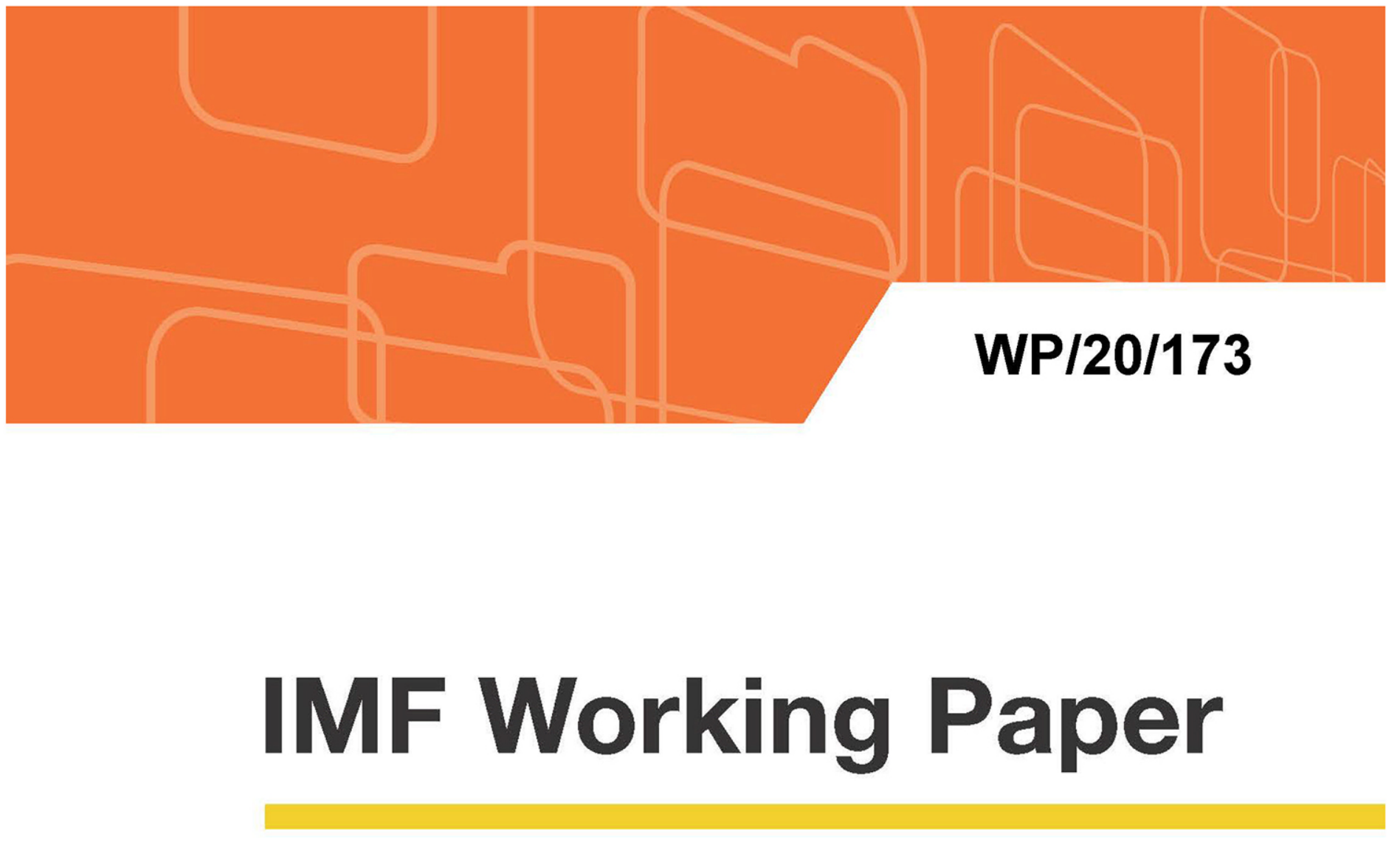

\title{
Destabilizing Stability? Exchange Rate Arrangements and Foreign Currency Debt
}

by Balazs Csonto and Tryggvi Gudmundsson

IMF Working Papers describe research in progress by the author(s) and are published to elicit comments and to encourage debate. The views expressed in IMF Working Papers are those of the author(s) and do not necessarily represent the views of the IMF, its Executive Board, or IMF management.

$$
\text { I N T E R N A T I O N A L M O N E T A R Y F U N D }
$$




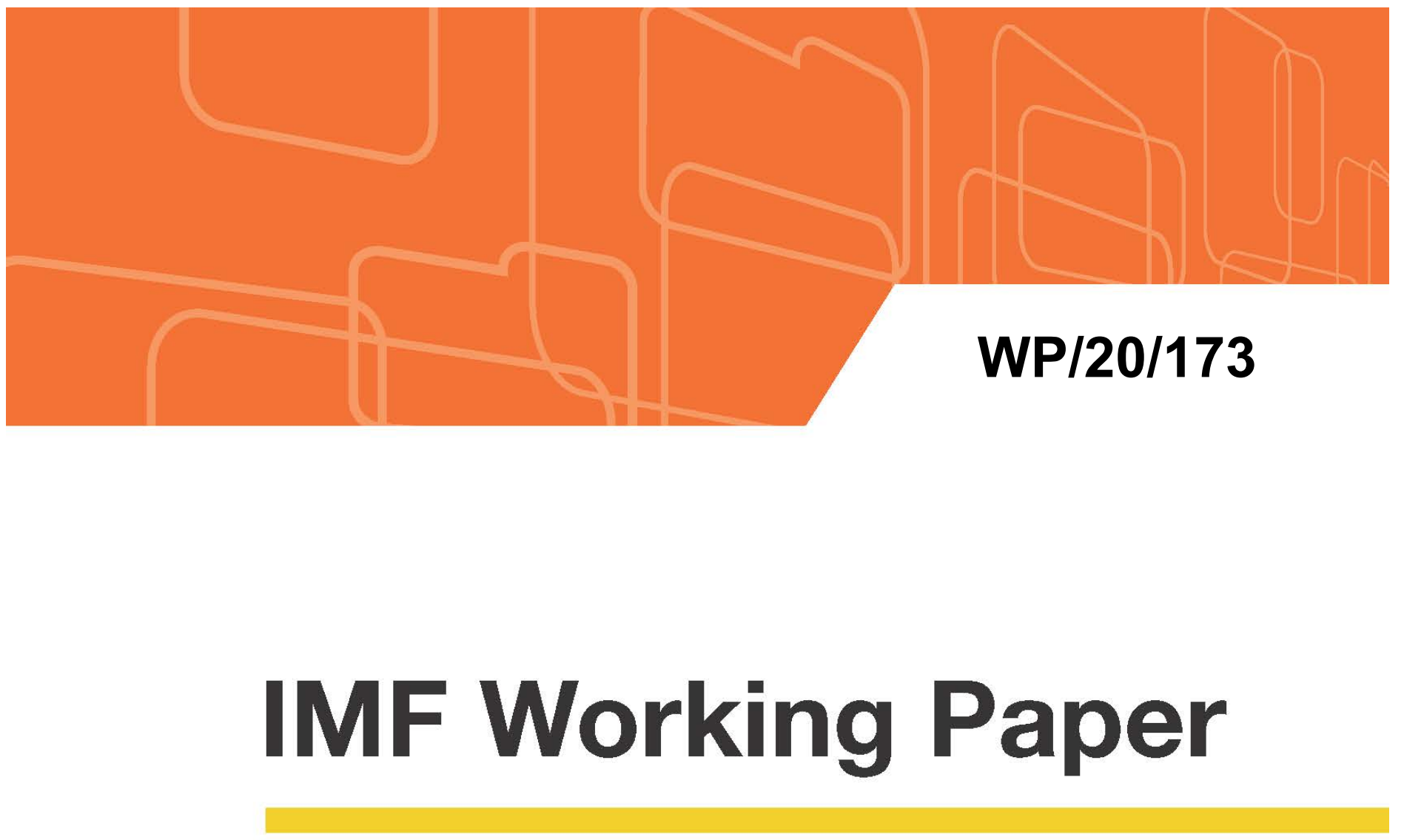

\section{Destabilizing Stability? Exchange Rate Arrangements and Foreign Currency Debt}

by Balazs Csonto and Tryggvi Gudmundsson

IMF Working Papers describe research in progress by the author(s) and are published to elicit comments and to encourage debate. The views expressed in IMF Working Papers are those of the author(s) and do not necessarily represent the views of the IMF, its Executive Board, or IMF management.

$$
\text { I N T E R N A T | O N A L M O N E T A R Y F U N D }
$$




\title{
IMF Working Paper
}

Strategy, Policy, and Review Department

\section{Destabilizing Stability? Exchange Rate Arrangements and Foreign Currency Debt Prepared by Balazs Csonto and Tryggvi Gudmundsson ${ }^{1}$}

Authorized for distribution by Rupa Duttagupta

August 2020

\section{IMF Working Papers describe research in progress by the author(s) and are published to elicit comments and to encourage debate. The views expressed in IMF Working Papers are those of the author(s) and do not necessarily represent the views of the IMF, its Executive Board, or IMF management.}

\begin{abstract}
Emerging markets (EMs) often respond to shocks by intervening in foreign exchange (FX) markets and thus preventing full exchange rate adjustment. This response can serve to dampen the effect of shocks and increase monetary policy space but may also incentivize economic participants to increase risk taking and take on more FX debt. This paper empirically analyzes the role of exchange rate flexibility in affecting such risk taking, by using rolling correlations and difference-in-difference estimations. The results suggest that a shift towards greater exchange rate flexibility often coincides with a decline in external FX debt. The findings also highlight the importance of using complementary policies to deal with financial stability issues related to the exchange rate, such as FXspecific macroprudential policies and policies aimed at promoting financial development.

JEL Classification Numbers: E52, E58, F31, F34, F40, O24

Keywords: Exchange Rate, FX Debt, External Debt, Monetary Policy, FX Intervention.

\footnotetext{
${ }^{1}$ We thank Yuting Shao for excellent research assistance. We also thank Ryadh Alkhareif, Tam Bayoumi, Rupa Duttagupta, Rishi Goyal, Vladimir Klyuev, Petya Koeva Brooks, Pau Rabanal, Umang Rawat, Jinhyuk Yoo, and seminar participants at the IMF's Strategy, Policy, and Review (SPR) Department for their helpful comments.
} 
Author's E-Mail Address: BCsonto@imf.org; TGudmundsson@imf.org

\section{Table of Contents}

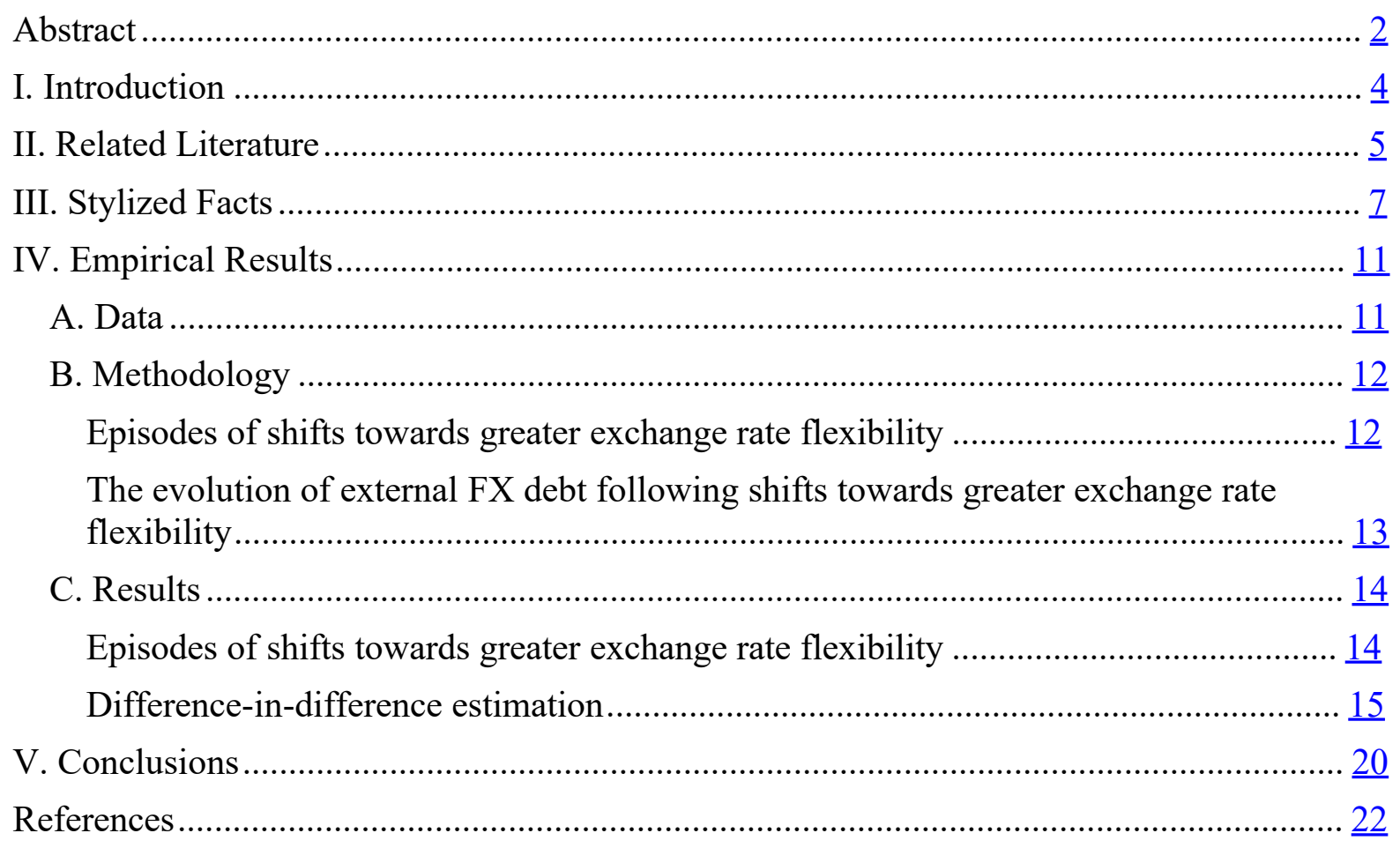




\section{INTRODUCTION}

Episodes of capital flow surges and withdrawals in emerging markets (EMs) present wellrecognized costs and benefits with a rich literature dedicated to exploring both. On the positive side, capital inflows provide an additional source of financing for countries which may have a limited domestic investor base. The flows themselves are also accompanied by an adjustment of prices and quantities to new information and changing fundamentals. Investors thus aid price discovery based on the relative attractiveness of a given country with subsequent effect on exchange rates and market interest rates. However, these episodes can also be disruptive, as documented in the sudden stop literature (Calvo, 1998) with the size of price adjustment potentially exceeding the level that fundamentals would warrant and thus result in overshooting (Dornbusch, 1976).

A key challenge for EM policymakers' is to facilitate a smooth adjustment process in the foreign exchange $(\mathrm{FX})$ market with changing relative fundamentals between the domestic and external environment. This challenge is not straightforward, however, as it involves an assessment of the underlying real-time change in fundamentals, translating that into the level of the equilibrium exchange rate accompanying those fundamentals, and a view on the extent to which active policy should prevent potential episodes of overshooting.

In recent decades, the reluctance by many EM policymakers to allow full adjustment of exchange rates following shocks has been documented extensively (see Section II). This socalled fear of floating is often explained by policymakers' low tolerance for exchange rate volatility in the presence of sizeable currency mismatches in domestic private or public sector balance sheets. Large exchange rate movements in the presence of such mismatches could result in balance of payments disruption and possible financial crises, thus inducing a reluctance to allow adjustment via the exchange rate channel.

In principle, however, the relationship between exchange rate flexibility and FX vulnerabilities can go in both directions. While reduced exchange rate flexibility may reduce the probability of a disruptive adjustment in the presence of balance sheet mismatches, this incomplete adjustment affects the perception of risks associated with the buildup of such mismatches. Therefore, a less flexible exchange rate could inadvertently create incentives to borrow in FX in order to exploit interest rate differentials. As high levels of foreign currency debt have been shown to be one indicator of heightened risk of financial crisis, the lack of exchange rate flexibility can contribute or exacerbate the buildup of material vulnerabilities. This potential contradiction whereby policy efforts to reduce volatility create an environment of increased risk taking has some parallels, albeit imperfect, with the work of Minsky (2008) wherein periods of financial stability lay the groundwork for greater risk taking and speculation which ultimately leads to instability and crisis.

This paper represents an attempt to assess the longer-term financial stability effects of preventing full exchange rate adjustment in the presence of shocks in EMs. We tackle this topic by exploring the relationship between exchange rate flexibility and FX vulnerabilities. We focus on the impact that FX stability has on the incentives of domestic agents to borrow in foreign currency. Given the inherent methodological challenges involved, most notably endogeneity issues and the slow-moving nature of the main variables of interest, we deploy difference-in-difference estimations. This does not fully remove potential complications 
regarding causality, but it allows for a somewhat richer examination of potential incentive effects of exchange rate smoothing.

We find that lower exchange rate flexibility is associated with higher levels of foreign currency debt. Despite some caveats which should be kept in mind, countries that introduce a more flexible exchange rate regime tend to experience a sharper reduction in foreign currency debt, providing evidence on the long-run financial stability benefits from greater exchange rate flexibility.

The remainder of the paper is structured as follows. Section II provides an overview of the literature and previous attempts to analyze exchange rate adjustments and FX intervention (FXI). Section III presents some stylized facts on the evolution of FX debt and exchange rate flexibility. Section IV presents the data, the methodology and the results. Section V concludes.

\section{RELATED LITERATURE}

The first building block to assessing potential long-term consequences of FXI is whether FXI in general is effective in altering market outcomes. In a case where FXI is unsuccessful in affecting either the level or the volatility of the exchange rate, any long-term effects on firm and household incentives would presumably be limited. There is a rich tradition of literature on this question with several studies, in particular, looking at EMs in the presence of volatile capital flows. Blanchard et al. (2015) look at FXI as a tool to address capital flow pressure and find that intervention does indeed reduce appreciation pressure during periods of inflows. Adler et al. (2019) similarly find evidence of a non-trivial effect of FXI on a country's exchange rate. Using an Instrumental Variable (IV) approach, they find that purchasing reserves of 1 percentage point of GDP leads to a 1.7-2 percent depreciation of the nominal exchange rate, and a slightly smaller impact on the real exchange rate. The picture is somewhat more nuanced for single-country studies. For example, Tapia and Tokman (2004) study intraday data in the foreign-exchange market and find limited impact of individual interventions in Chile, while Kamil (2008), using a two-stage IV approach, looks at the case of Colombia and finds that only a subset of interventions was effective in stemming domestic currency appreciation.

Turning to financial stability aspects of FXI, several papers have looked at the relationship between the exchange rate regime and foreign currency debt. In a widely cited paper, Eichengreen and Hausmann (1999) compare and contrast the moral hazard argument between exchange rates and financial fragility to the original sin hypothesis and issues of commitment. A large strand of the related empirical literature focuses on single countries and the effect of specific regime changes on debt compositions. These studies typically find an inverse relationship between exchange rate flexibility and the level of foreign currency exposure among corporates. This includes Cowan and De Gregorio (2007), who find that Chilean firms' FX exposure decreased after the authorities' move towards a floating exchange rate regime. Albagli et al. (2020), also looking at the Chilean case, document the decline in exposure post-float but argue that other factors could also have contributed, including the deepening of financial markets. Martinez and Werner (2002) find a similar reduction for Mexico following its 1994 regime shift, while Pratap et al. (2003) find evidence of greater currency matching by Mexican exporters following the introduction of the floating 
exchange rate. While much of the work in this field focuses on the two extremes of pegs versus fully floating, Patnaik and Shah (2010) find similar evidence of a negative relationship between FX volatility and foreign currency exposure for Indian firms during four periods of varying volatility.

Other work in the literature examines cross-country differences, as opposed to the singlecountry approach above. Kamil (2012) looks at non-financial corporates in six Latin American economies and finds that a move towards floating exchange rates leads to a reduction in firms' foreign currency exposures. Parsley and Popper (2006) use firm-level data to analyze foreign currency exposure in nine Asian economies and find that the exposure is higher under pegged regimes. Tong and Wei (2019) study corporate leverage and FX reserve holdings for 6610 non-financial firms in 23 EMs. They find that greater reserve accumulation leads to higher leverage, although it should be caveated that their study focuses exclusively on reserves which may induce a different risk-taking response than that of FXI or the exchange rate regime.

Berkmen and Cavallo (2009) look at the relationship between exchange rate policy choice and liability dollarization. They find that countries with high liability dollarization more frequently attempt to stabilize the exchange rate but find little evidence of the opposite causal relationship, from exchange rate stabilization to dollarization. Ghosh et al. (2014) study varying degrees of flexibility of 50 EMs over a 31-year period. They conclude that free floats are the least vulnerable to crisis while the results for the increasingly popular managed floaters are more mixed. Kim et al. (2020) look at the issue of FXI and foreign currency debt directly, focusing on firm-level data as opposed to the more aggregate data used in this paper, and find a positive association between the two.

BIS (2013) provides context for much of the results in the empirical literature by reviewing EM policymakers' experience of capital flows and policy responses. Their survey of central bankers suggested concerns that FXI could indeed alter incentives of the private sector by restricting flexibility and encouraging greater speculation. However, covering a wide range of EMs experience, there is no unanimity regarding the extent of risk-taking that FXI induces. This risk must, in turn, be weighed against the benefit of volatility reduction and subsequent macroeconomic outcomes. Several cases within the BIS volume suggest that FXI does on net have a useful role in smoothing fluctuations.

Finally, classifying these possible long-term effects of FXI as negative relies on the assumption that higher FX debt, beyond some prudent level, does indeed increase vulnerabilities. Bordo et al. (2010) find a positive association between foreign currency debt and the risk of crisis as well as that between crises and permanent output losses. Similarly, IMF (2020) find that FX debt liabilities increase the likelihood of an external crisis, especially in EMs and developing economies. Moreover, they also show that pre-existing elevated FX debt levels amplify the macroeconomic costs of an external crisis.

While a lot of the literature focuses on the extent to which significant levels of FX debt raise the probability of a crisis and its potential costs, FX debt can also weigh on activity in a noncrisis environment. This is the case when financial conditions become determined to a greater extent by exchange rate developments, which are in turn partially exogenous and outside domestic policymakers' control. Bebczuk et al. (2006) find a negative relationship between large foreign currency debt levels and growth following a real exchange rate depreciation. 
These balance sheet effects from currency movements have come into greater focus in the literature in recent years alongside the expansion of debt in EMs and low-income countries, many of whom either borrow directly in foreign currency, or in local currency but from international investors who experience losses when the borrowing country's currency depreciates.

In sum, there is a large literature on EMs' attempts to use exchange rate policy to reduce the effect of external shocks. While the evidence on FXI in general is somewhat mixed, several studies find them to have a non-trivial effect on the exchange rate. The picture regarding financial stability aspects of exchange rate policies is also somewhat nuanced, but both empirical studies and surveys of policymakers suggest that intervention can indeed alter the behavior of the private sector when it comes to exposure to foreign debt. The rest of the paper attempts to enrich and update this strand of literature with both a more aggregate view than many papers take as well as a different approach, in the form of difference-in-difference estimation. The next section lays out some stylized facts in the data before moving on to our empirical estimates.

\section{STYLIZEd FACTS}

External FX debt was within the range of 30-50 percent of GDP for most EMs in the past three decades (Figure 1). It increased sharply in the late-1990s, driven by a combination of rising external borrowing and the continuation of the "original sin" (i.e. the dominance of FX debt in total debt). The increase was exacerbated by valuation effects following the depreciation of EM currencies during a series of crisis events (Asia, 1997; Russia, 1998; Argentina, 2001). This trend subsequently started to reverse, however, with external FX debt decreasing gradually in the mid-2000s leading up to the Global Financial Crisis (GFC). This period saw an increase in FX borrowing by households and non-financial corporates in a few countries in Central and Eastern Europe, however, possibly reflecting the combination of a relatively high interest rate differential, moderate exchange rate volatility, and an expectation of convergence-induced real appreciation. Following the GFC, external FX debt has increased slightly on aggregate in EMs, although with a concurrent decline in the share of external debt denominated in foreign currency possibly reflecting the development of local currency financial markets and a deepening domestic investor base in many countries. 
Figure 1. Emerging Markets: External FX Debt

Following a steady decline in the 2000s, external FX debt

.... while the share of FX debt in total external debt has has remained broadly stable since the GFC...

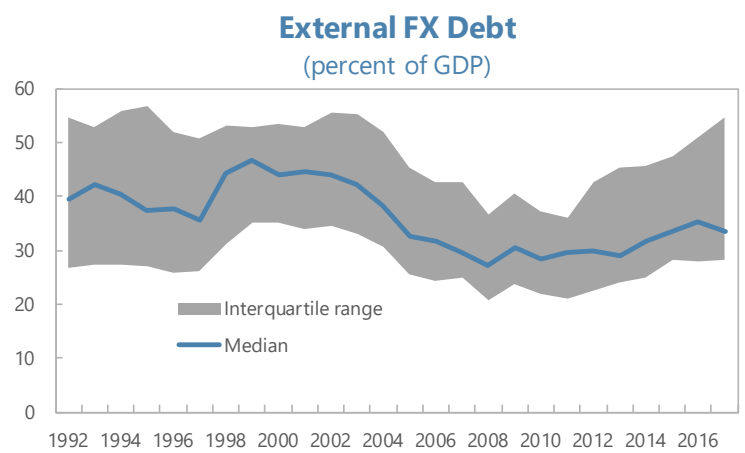
decreased somewhat but remained at an elevated level

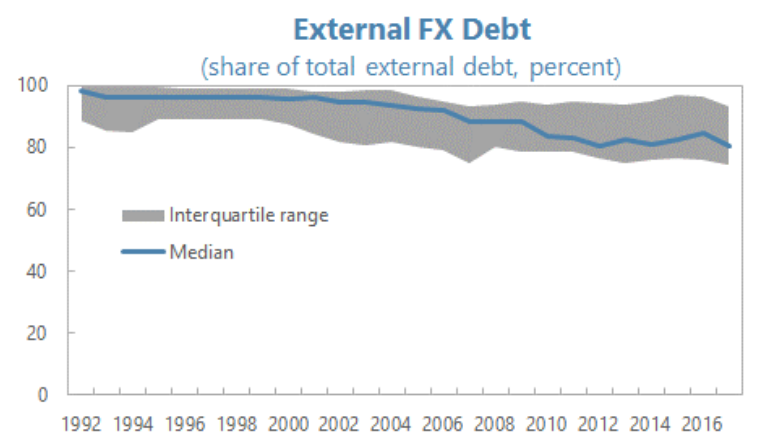

Sources: Bénétrix et al. (2019), staff calculations

The decision to borrow in FX could, as mentioned above, be driven by the desire to exploit the interest rate differential. This is particularly the case if (i) exchange rate volatility is moderate; (ii) there is an expectation that the local currency will appreciate over the medium term (e.g., due to economic convergence); or (iii) there are economic participants that would not be able to finance their loans at the relatively high local-currency interest rates. ${ }^{2,3}$ At the same time, the expected balance of return (carry trade) and risks (depreciation of the currency) often changes with market sentiment. For example, periods of heightened market volatility such as the early 2000 s or the GFC were characterized by an increase in interest rate differentials, with any positive impact on the attractiveness of FX loans offset by heightened exchange rate volatility and periods of sharp depreciation (Figure 2). However, the combination of relatively high, albeit decreasing, interest rate differentials and moderate exchange rate volatility provided strong incentives to borrow in FX in the mid-2000s across EMs.

\footnotetext{
${ }^{2}$ Liquidity-constrained participants might include households and non-financial corporations borrowing in FX from domestic banks. This, in turn, would lead to higher external FX debt if domestic banks procure funding from abroad.

${ }^{3}$ Other motives include hedging (in the presence of FX assets and/or income), the availability of intercompany funding or the desire to gain access to foreign investors (e.g., in the case of the sovereign).
} 


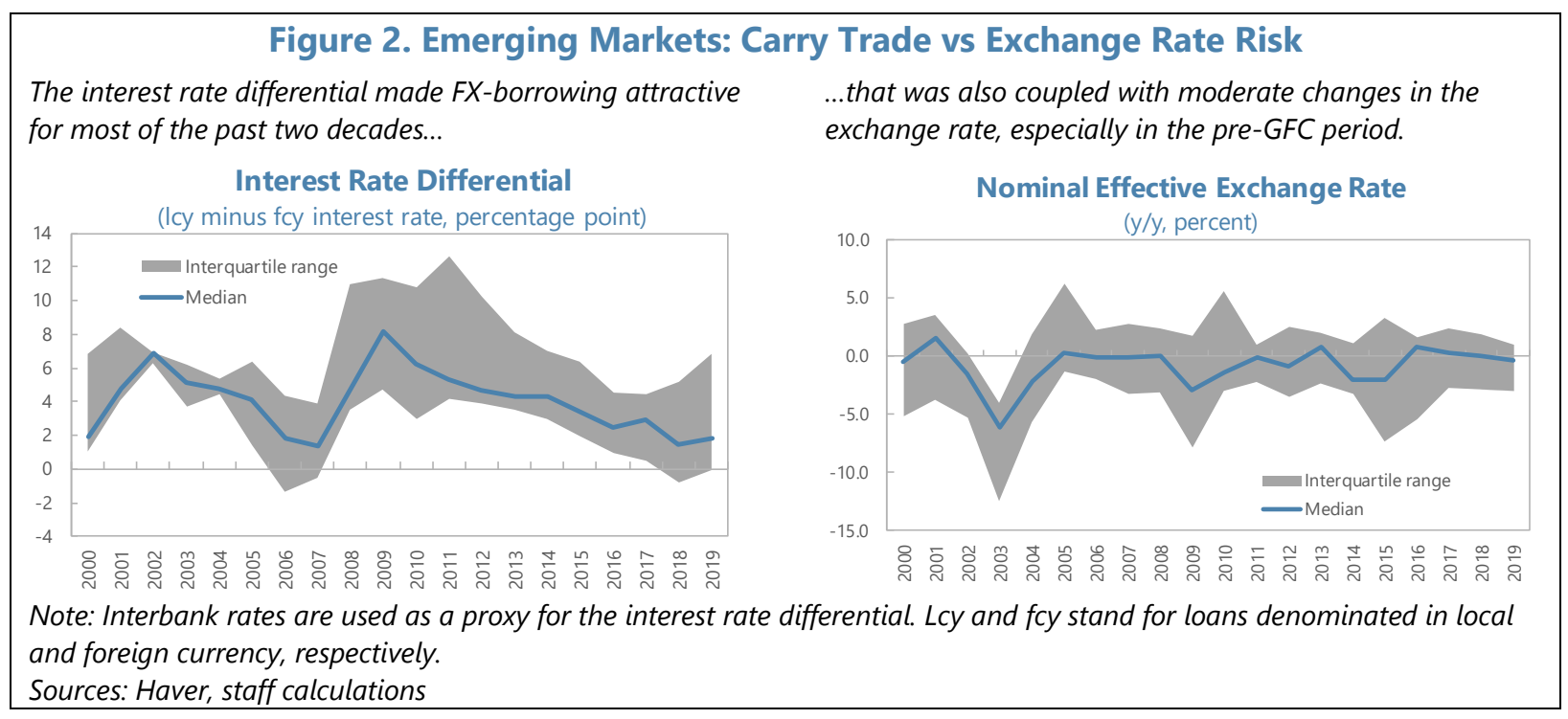

In addition to swings in market sentiment, changes in exchange rate regimes also affected the degree of exchange rate volatility in EMs. Between the 1990s and the mid-2000s, there was a decline in the number of intermediate regimes while both fixed and flexible regimes gained popularity (Figure 3). During the same period, especially in the 2000s, FXI was predominantly on the purchasing side, often motivated by precautionary reserve accumulation. A large part of this sharp increase in global savings found its way into U.S. Treasury securities in the form of purchases by several EM central banks ("global savings glut," as explored, for example, in Bernanke (2005)). This was followed by a shift away from less flexible exchange rate regimes in response to increased FX market volatility (IMF, 2012) as well as the use of FXI to counter depreciation pressure during periods of market stress such as the GFC, the Taper Tantrum of 2013, and the 2018 EM selloff. During the short period between 2009-11, however, unconventional monetary policies in major advanced economies and the resulting search-for-yield behavior led to sharp capital inflows into EMs, triggering FXI aimed at stemming the appreciation of their currencies and an increasing share in intermediate regimes in which exchange rate movements were more tightly managed. 


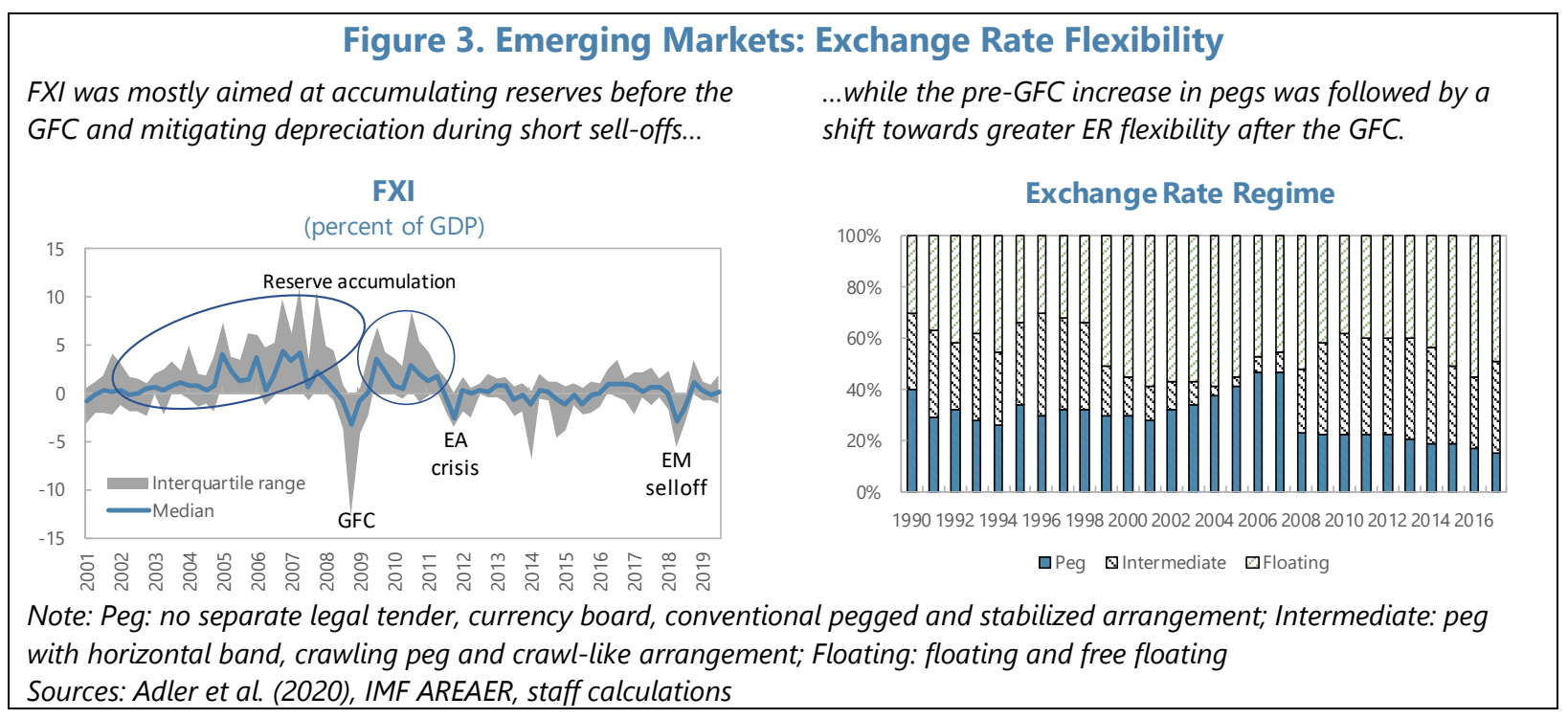

In line with the above-described mechanisms, rolling correlations indicate a positive relationship between external FX debt and the intensity of the use of FXI for most of the period of 2003-17 (with the notable exception of the period around the GFC) ${ }^{4}$, albeit significant in only a few sub-periods (Figure 4). The results are broadly similar when rolling correlations are calculated for annual and 5 -year periods, i.e., the relationship is positive in most periods, with varying levels of significance. Given that the rolling correlations do not necessarily imply causal relationship, this could indicate either the lower tolerance of the central bank for exchange rate volatility (i.e. higher total FXI) in the presence of high external FX debt, higher willingness of economic participants to exploit the interest rate differential (i.e. higher external FX debt) in the presence of active exchange rate management, or any combination thereof. The underlying reason notwithstanding, the data point to a positive association between external debt levels and the activity of central banks in FX markets. The next section looks more closely at this relationship for a sample of EMs.

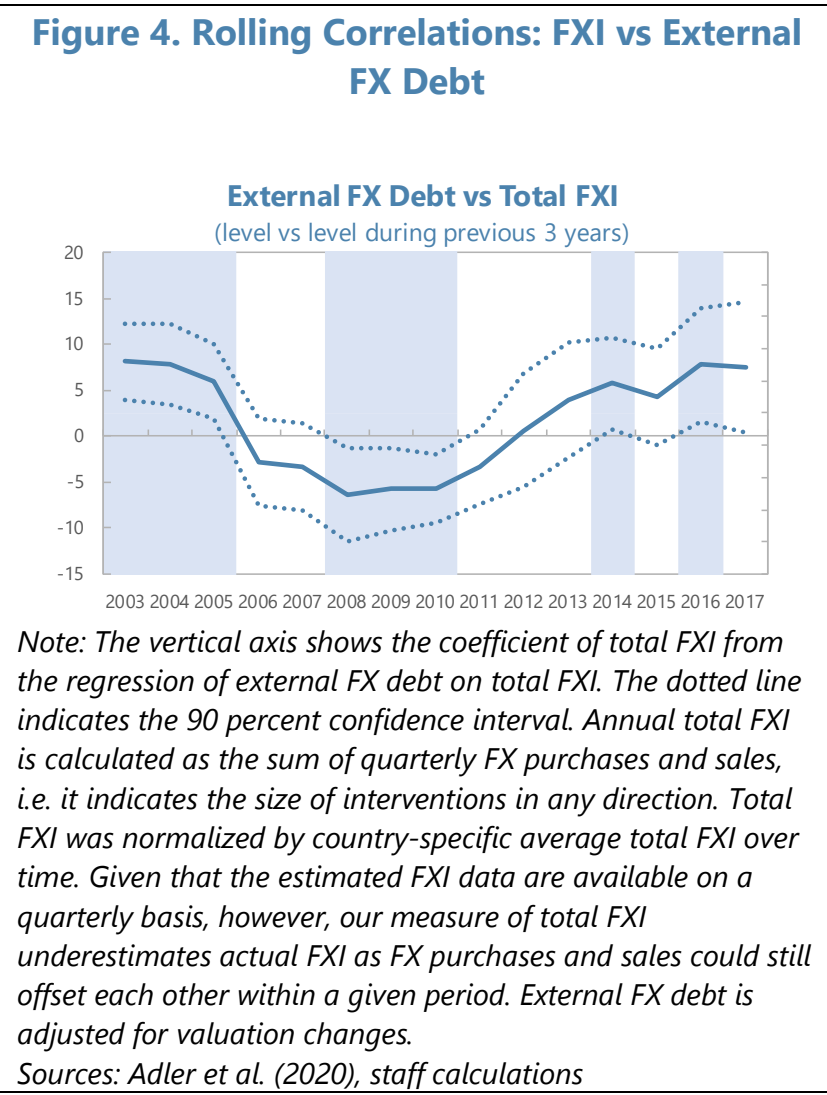

Figure 4. Rolling Correlations: FXI vs External FX Debt 


\section{EMPIRICAL RESUlTS}

A. Data

Our sample includes annual data for 24 EMs between 1990 and 2017. 5 The countries include Argentina, Brazil, Chile, China, Colombia, Egypt, Guatemala, Hungary, India, Indonesia, Malaysia, Mexico, Morocco, Pakistan, Peru, Philippines, Poland, Russia, South Africa, Sri Lanka, Thailand, Tunisia, Turkey and Uruguay. Our main indicators of interest are FX debt and exchange rate flexibility.

For $F X$ debt, our variable is external $\mathrm{FX}$ debt. The reasons for choosing this specification are twofold. First, external FX debt has a comprehensive coverage of sectors, including the FX debt of households, non-financial and financial corporations, and the general government borrowed from abroad, thereby allowing for an assessment of overall risks. ${ }^{6}$ Although households and non-financial corporations typically borrow from domestic financial institutions, external FX debt might still capture the debt of these sectors indirectly to some extent if their domestic lender acquired the necessary funding from abroad. In this case, for example, the FX debt of a company obtained from a domestic bank that in turn borrowed the funds from abroad would still be part of the country's external FX debt.

The second reason for using external FX debt is that the recently published dataset by Bénétrix et al. (2019) includes comprehensive annual data on the level and currency composition of external assets and liabilities for a large number of EMs for the period of 1990-2017. Given the information on the currency composition of debt with a breakdown into the SDR currencies, this allows for an adjustment for valuation changes in external FX debt.

As a proxy for exchange rate flexibility, our main variable is the exchange rate regime. The reasons are again twofold. First, the dataset for de facto exchange rate arrangements, from the IMF's Annual Report on Exchange Arrangements (AREAER), is available for most EMs during the period of 1990-2017. There is a break in the series, however, as the classification system was modified in 2009. Some changes included, for example, the replacement of managed and independent floating with floating and free floating, respectively, and a clear distinction between formal fixed (peg-like) and crawling pegs (crawl-like); (Habermeier et al., 2009). In order to map the pre- and post-revision regimes with each other, we followed Habermeier et al. (2009) (Table 1).

The use of the exchange rate regime also has the benefit, unlike other variables such as FXI, that - conditional on the credibility of the regime - It might give a clearer indication of the perception of exchange rate risk that is the main factor behind the decision to borrow in FX. As discussed in the previous section, FXI does not necessarily aim at reducing exchange rate volatility. For example, FXI mostly aimed at accumulating international reserve in several EMs in the pre-GFC period. Also, during risk-off periods, the volatility of the exchange rate can still be high even in the presence of FXI, so the intense use of FXI does not necessarily

\footnotetext{
${ }^{5}$ The definition of EMs is in line with that in the Fund's Vulnerability Exercise for Emerging Markets (VEE) exercise that includes 54 countries. Data availability, however, restricted the sample to 24 EMs.
} 
eliminate (the perception of) exchange rate risk for borrowers. Nevertheless, there is a negative association between the degree of the flexibility of the exchange rate regime and the intensity of FXI, with more intense use of FXI under pegged regimes (Figure 5).

\section{B. Methodology}

We consider changes in external FX debt in the aftermath of shifts towards greater exchange rate flexibility in the countries undertaking the regime shift relative to other countries. The main challenge, as mentioned in previous sections, is that there is a two-way relationship between FX debt and exchange rate flexibility. Therefore, we apply a two-step process: (i) we identify episodes of shifts towards more flexible

Figure 5. Average Estimated FXI Across Exchange Rate Regimes, 1980-2019 (percent of GDP)

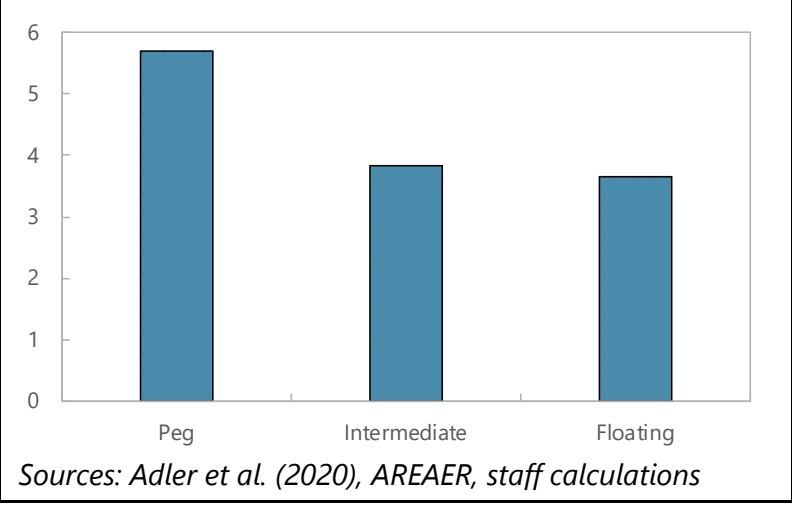
exchange rate regimes (treatment), the countries undertaking these changes (treated group), as well as a control group of countries used as proxy for the counterfactual scenario of no regime shift (control group); (ii) we compare changes in external FX debt following the treatment between the treated and the control group in a difference-in-difference framework. This contrasts with many previous studies, which are concerned with quantifying the effects of individual regime shocks on debt over time, as opposed to an inherent counterfactual framework as the difference-in-difference approach provides.

\section{Episodes of shifts towards greater exchange rate flexibility}

In the first step, we use the classification of exchange rate arrangements from the AREAER (see IMF (2019) for the latest report) to identify episodes of shifts towards greater exchange rate flexibility. Specifically, we classified the exchange rate regimes into the following three categories: (i) peg: no separate legal tender, currency board, conventional pegged and stabilized arrangement; (ii) intermediate: peg with horizontal band, crawling peg and crawllike arrangement; and (iii) floating: floating and free floating (Table 1).

\section{Table 1. Classification of Exchange Rate Arrangements}

\begin{tabular}{|c|c|c|c|}
\hline & & 1998 de facto system & 2009 de facto system \\
\hline \multirow[t]{2}{*}{ Peg } & Hard peg & $\begin{array}{l}\text { No separate legal tender } \\
\text { Currency board }\end{array}$ & $\begin{array}{l}\text { No separate legal tender } \\
\text { Currency board }\end{array}$ \\
\hline & Soft peg & Conventional fixed peg & $\begin{array}{l}\text { Conventional pegged arrangement } \\
\text { Stabilized arrangement }\end{array}$ \\
\hline Intermediate & $\begin{array}{l}\text { Intermediate } \\
\text { peg }\end{array}$ & $\begin{array}{l}\text { Peg with horizontal band } \\
\text { Crawling peg } \\
\text { Crawling band }\end{array}$ & $\begin{array}{l}\text { Peg with horizontal band } \\
\text { Crawling peg } \\
\text { Crawl-like arrangement }\end{array}$ \\
\hline Floating & & $\begin{array}{l}\text { Managed floating } \\
\text { Independently floating }\end{array}$ & $\begin{array}{l}\text { Floating } \\
\text { Free floating }\end{array}$ \\
\hline
\end{tabular}


We then use three criteria to define shifts towards greater exchange rate flexibility: (i) the exchange rate regime changes from peg to intermediate or floating, or from intermediate to floating; (ii) the regime change was not preceded by an opposite change - a shift from more to less flexible exchange rate regime - over the previous five years, i.e. the change does not reflect a reversal to the "default" regime following a temporary period in the given country; and (iii) the change is not followed by a reversal for at least five years, i.e. it is a medium- or long-term shift to greater exchange rate flexibility.

With the aim of understanding a potential counterfactual scenario, two control groups are considered: a control group consisting of all other EMs, and a control group including countries with fixed exchange rate regimes. While the latter provides a more relevant comparison for the evolution of external FX debt following the shift towards greater exchange rate flexibility, the first can also be a useful benchmark.

\section{The evolution of external FX debt following shifts towards greater exchange rate flexibility}

In the second step, we analyze changes in external FX debt in the aftermath of shifts towards greater exchange rate flexibility (treatment) in the countries undertaking the regime shift (treated group) relative to others (control group) in a difference-in-difference framework. Specifically, we consider the 5-year periods before and after the regime change in order to understand the potential impact of the regime change.

First, we estimate the following equation:

$$
\begin{gathered}
F X \text { debt }_{i t}=\beta_{0}+\beta_{1} D(\text { treated })_{i}+\beta_{2} D\left(\text { post }- \text { treatment }_{t}+\beta_{3} D(\text { treated })_{i}\right. \\
* D(\text { post }- \text { treatment })_{t}+\varepsilon_{i t}
\end{gathered}
$$

where $F X$ debt is external $\mathrm{FX}$ debt, $D$ (treated) is a dummy equal to one for countries undertaking the shift towards greater exchange rate flexibility (treated group), $D$ (post treatment) is a dummy equal to one for periods between $t+1$ and $t+5$ (following the treatment), while $i$ and $t$ indicate countries (both treated and control) and years (ranging from $t-5$ to $t+5$ where $t$ is the time of the regime shift), respectively. The interaction term $D($ treated $) * D$ (post - treatment $)$ is the difference-in-difference estimator, indicating whether the level of external FX debt was lower in countries shifting towards greater exchange rate flexibility following the regime change.

Second, given that external FX debt might have followed a declining trend across countries (see Section III), we introduce time trend in the following specification:

$$
\begin{gathered}
\text { FXdebt } t_{i t}=\beta_{0}+\beta_{1} t+\beta_{2} t * D(\text { treated })_{i}+\beta_{3} t * D(\text { post }- \text { treatment })_{t}+\beta_{4} t \\
* D(\text { treated })_{i} * D(\text { post }- \text { treatment })_{t}+\varepsilon_{i t}
\end{gathered}
$$

where $t$ indicates the time trend in the evolution of external FX debt, while the difference-indifference estimator $t * D$ (treated $) * D$ (post - treatment $)$ indicates whether the trend changes in countries shifting towards greater exchange rate flexibility following the regime change. 


\section{Results}

Following the two-step empirical strategy, the results on the identification of episodes of shifts towards greater exchange rate flexibility are presented below, followed by the results of the difference-in-difference estimation on the evolution of external FX debt during these episodes.

\section{Episodes of shifts towards greater exchange rate flexibility}

We identified 26 episodes of shifts towards greater exchange rate flexibility for our sample period and countries. The large majority of these episodes entailed a shift from peg to floating (12 episodes) or from intermediate to floating (12 episodes), with only two episodes of shifts from peg to intermediate (Figure 6). In other words, countries switched directly to floating regimes during 24 episodes out of 26 , in line with the general trend of declining popularity of intermediate regimes across countries in the 1990s and the 2000s (IMF, 2003; Ghosh et al. 2011).

There was a clustering of episodes during three main periods: the second half of the 1990s until the early 2000s, the mid-2000s, and the mid-2010s. Most episodes took place in Asia (12 episodes), Latin America and the Caribbean (LAC) (6 episodes), and Europe (5 episodes) $;{ }^{7}$ however, there were also a few episodes in the Middle East and North Africa (MENA) (2 episodes) and the Commonwealth of Independent States (CIS) (1 episode).

The decision to move towards greater exchange rate flexibility reflected several factors across these episodes:

- A major factor was the change in the monetary policy frameworks in EMs that affected the role of the exchange rate in the economy. For example, many economies in emerging Europe experienced surging inflation due to the combination of price and wage liberalization, monetary financing in some cases, and limited experience in the conduct of monetary policy in a market economy in the early 1990s (Belhocine et al., 2016). This resulted in the adoption of an exchange rate anchor with the aim of stabilizing inflation expectations and gaining policy credibility. Following the stabilization period, however, the inherent conflict between lowering inflation through the pegged exchange rate and maintaining external competitiveness led to increasing exchange rate flexibility, including through crawling arrangements (e.g., Poland in 1991) (IMF, 2003). Moreover, the decline in the number of EMs with an exchange rate anchor was mirrored by the tendency to adopt inflation targeting (IT) frameworks starting at the end of the 1990s. Specifically, between 1998 and 2002, the number of EMs with IT increased from zero to 10, while the number of those with an exchange rate anchor decreased from 13 to 4 in our sample. For our sample, Chile was among the first EMs to adopt IT and free floating in 1999. Hungary also adopted IT in 2001; however, the horizontal band was replaced with a floating exchange rate, allowing the central bank to fully focus on the inflation target only in 2008 . At the same time, Turkey shifted to free floating in 2001 but adopted a monetary aggregate target as the conditions for IT were not yet met.

\footnotetext{
${ }^{7}$ This, however, is partly the result of the dominance of countries from these regions in the sample.
} 
- Another crucial factor affecting the conduct of monetary policy in EMs was the increasing integration into international capital markets. According to the international trilemma, the wave of capital account liberalization across EMs in the 1990s implied the loss of the ability to conduct independent monetary policy in the presence of fixed exchange rates. In other words, the decision to increase exchange rate flexibility helped enhance monetary policy independence. ${ }^{8}$ At the same time, a few EMs gave up their fixed exchange rate regime against the backdrop of financial turbulence (e.g., Indonesia in 1997).

Figure 6. Episodes of shifts towards greater exchange rate flexibility

Most episodes took place during the second half of the 1990s, the mid-2000s and mid-2010s, predominantly in Asia, Europe and $L A C$, and from peg or intermediate to floating.
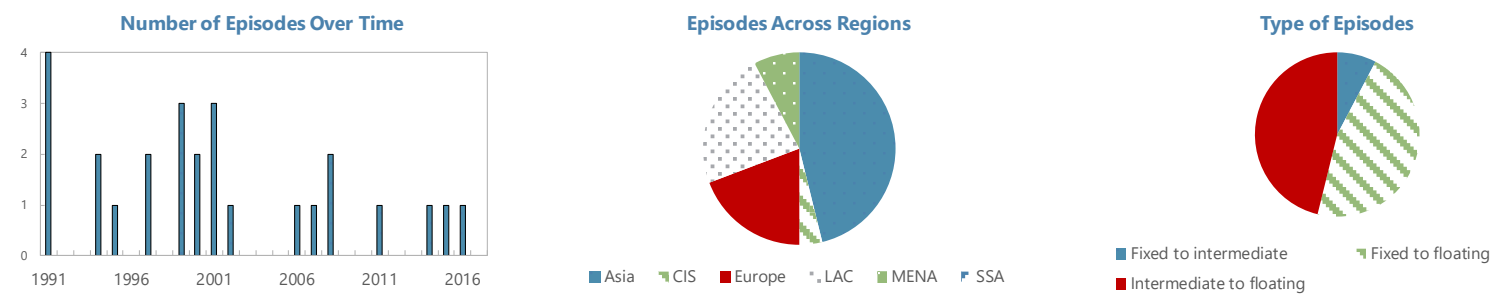

Sources: AREAER, staff calculations

\section{Difference-in-difference estimation}

During the 26 episodes identified above, external FX debt was on a declining path both before and after the shift to greater exchange rate flexibility in the treated group (Figure 7). Moreover, the declining path was also prevalent in both control groups (all other countries and countries with a fixed exchange rate regimes). Visual inspection of the evolution of external FX debt, however, highlights a few interesting differences between the treated and the control group, as well as between the two control groups. First, the rate of the decline before the regime shift was broadly similar between the treated group and the control group with fixed exchange rate regimes, while it was slightly larger in the control group including all other countries. Second, while the rate of decline seems to have been broadly stable throughout the entire period (i.e., between $t-5$ and $t+5$ ) in both control groups, it accelerated in the treated group following the treatment. This could reflect a change in the balance of risk-return analysis due to the perception of rising exchange rate risk. One wellknown example is Chile, where the abandonment of the target zone for the exchange rate in 1999 was followed by a significant reduction in corporate currency mismatches (Claro and Soto, 2013) as well as a decline in our measure of valuation-adjusted external FX debt. Chile's case confirmed that a shift to a floating regime could endogenously handle the fear of floating by supporting economic transformation, including through smaller balance sheet mismatches (Albagli et al., 2020). In other words, a credible regime shift could alter the riskreturn characteristics of borrowing in favor of local currency loans, thereby reducing the fearof-floating arising from currency mismatches.

\footnotetext{
${ }^{8}$ Rey (2015), however, argues that the presence of a global financial cycle affects the conduct of monetary policy irrespectively of the exchange rate regime in the case of open capital accounts (dilemma instead of trilemma).
} 
Figure 7. External FX Debt vs Shifts Towards Greater Exchange Rate Flexibility

(cumulative change in external FX debt relative to the last period before the exchange rate regime shift, mean, percent of GDP)

In countries that switched to more flexible exchange rate regimes, external FX debt decreased over the medium term relative to countries with fixed exchange rate regime.

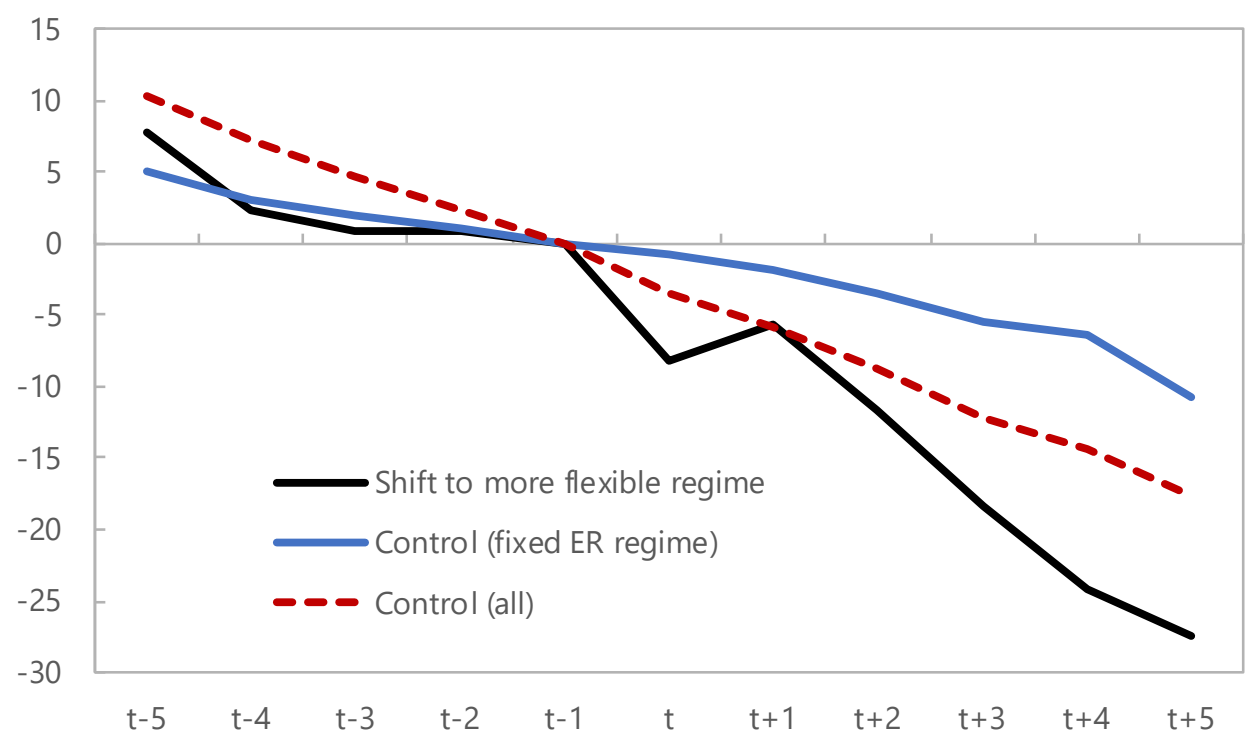

Note: Control group of countries with fixed exchange rate regime includes those that kept their pegs, while control group with all countries also includes those who did not change their regime and already had a more flexible regime. Sources: staff calculations

The findings based on the visual inspection of the evolution of external FX debt are confirmed by the results from the difference-in-difference estimation as described in the previous section (Equations 1 and 2) (Table 2). ${ }^{9}$ Specifically, in the first column (Eq. 1), the coefficient of the difference-in-difference estimator $(D$ (treated $) * D$ (post - treatment $))$ suggests that the level of external FX debt was significantly lower in countries undertaking the regime shift. The results in the second column (Eq. 2) suggest the presence of a time trend, with external FX debt decreasing by around 2 percent of GDP per year across countries. Moreover, the difference-in-difference estimator $(t * D$ (treated $) *$ $D$ (post - treatment $)$ ) is also significant, indicating that the rate of decline accelerated by around 0.9 percent of GDP in countries undertaking a shift towards a more flexible exchange rate regime following the shift.

\footnotetext{
${ }^{9}$ In the estimations, we use the control group of countries with fixed exchange rate regime as this is a more relevant comparison for the post-treatment evolution of external FX debt.
} 
Table 2. Difference-in-difference estimation results

Dependent variable: External FX Debt

(1)

1.924

$(3.035)$

\begin{tabular}{|c|c|c|}
\hline & & \\
\hline $\mathrm{D}$ (treated) & 1.924 & \\
\hline & $(3.035)$ & \\
\hline $\mathrm{D}$ (post-treatment) & $-6.775 * * *$ & \\
\hline & $(1.643)$ & \\
\hline $\mathrm{D}($ treated $) * \mathrm{D}$ (post-treatment $)$ & $-9.311 * *$ & \\
\hline & $(2.413)$ & \\
\hline Time trend & & $-2.027 * * *$ \\
\hline & & $(0.510)$ \\
\hline Trend*D(treated) & & -0.207 \\
\hline & & $(0.600)$ \\
\hline Trend*D(post-treatment) & & 0.359 \\
\hline & & $(0.364)$ \\
\hline Trend*D(treated)*D(post-treatment) & & $-0.940 *$ \\
\hline & & $(0.486)$ \\
\hline Constant & $4.106^{* *}$ & $13.198 * * *$ \\
\hline & $(2.054)$ & $(2.170)$ \\
\hline R-squared & 0.13 & 0.18 \\
\hline
\end{tabular}

Source: authors' calculations.

Note: The estimations are based on 11 periods ( $t-5$ to $t+5)$ and 52 groups (corresponding to the number of episodes of 26 and the number of controls of 26). The control group is the group of countries with fixed exchange rate regime (blue line on Figure 7) as this control group is more relevant for understanding the impact on external debt of the stability of the exchange rate.

There are a few potential caveats, however, to be made with regard to these results, including (i) whether the treated and the control group would have experienced the same trend in the absence of the treatment; (ii) the possible impact of crises episodes on the evolution of external FX debt; (iii) the implication of the results for non-financial private sector FX debt; (iv)the possible impact of other reforms on the evolution of FX debt; (v) whether other policies played a potential role in driving the decrease in external FX debt during these episodes; and (vi) any implication for exchange rate policies is subject to further considerations such as the emergence of disorderly market conditions that might necessitate the use of tools such as FXI under flexible exchange rate regimes as well.

First, with the aim of understanding whether the treated and the control group exhibit the same trend in the absence of treatment, we estimate the following equation only for the pretreatment period:

$$
F X \text { debt }_{i t}=\beta_{0}+\beta_{1} t+\beta_{2} t * D(\text { treated })_{i}+\varepsilon_{i t}
$$


where any difference between the trend of the treated and the control group would be indicated by the coefficient of the interaction of the time trend and the treated dummy being statistically significant. Our results suggest that external FX debt did not exhibit a different trend in the treated and the control group as the interaction of the trend and the dummy for the treated group was not statistically significant (see Text Table). This is in line with our baseline results where the interaction terms were not significant either (Table 2).

Text Table. Pre-Treatment Trend Dependent variable: External FX Debt

\begin{tabular}{|lc|}
\hline Time trend & $-1.281^{* * *}$ \\
& $(0.411)$ \\
Time trend ${ }^{*} \mathrm{D}$ (treated) & -0.304 \\
& $(0.588)$ \\
Constant & $10.999^{* * *}$ \\
& $(2.717)$ \\
\hline R-squared & 0.01 \\
\hline Note: For periods between $\mathrm{t}-5$ and $\mathrm{t}-1$. \\
\hline
\end{tabular}
This suggests that our baseline results are not driven by the fact that the selection of treatment countries were inherently more likely to experience a decline in debt.

Second, countries that switch to more flexible regimes might have been forced to abandon pegs as they were no longer sustainable in a crisis, with the crisis also reducing market access, thereby leading to a decline in debt. This, however, does not change the main takeaway, as the crisis itself would still signal the long-term implications of exchange rate stability for financial stability to the extent exchange rate stability contributed to the crisis. Indeed, in our sample, there are a few episodes entailing crisis, with the combination of fixed exchange rate and FX debt playing an important role in the run-up to the crisis (e.g., Indonesia and Thailand in 1997).

Third, the decline in external FX debt might have been driven by public external FX debt to a large extent that in turn might reflect the underdevelopment of local currency bond markets. As such, the results based on external FX debt might have limited usefulness in understanding the behavior of the nonfinancial sector FX debt. Nevertheless, the positive relationship between the FX debt of the non-financial private sector and external FX debt across countries suggests that the results based on the use of external FX debt could still be used to draw implications for non-financial private sector FX debt as well (Figure 8). ${ }^{10}$

Fourth, the shift to a more flexible exchange rate regime is often accompanied by other reforms, including changes in the monetary policy framework or institutional Figure 8. External vs Households' and NonFinancial Corporations FX Debt (percent of GDP) arrangements. Therefore, the decline in FX

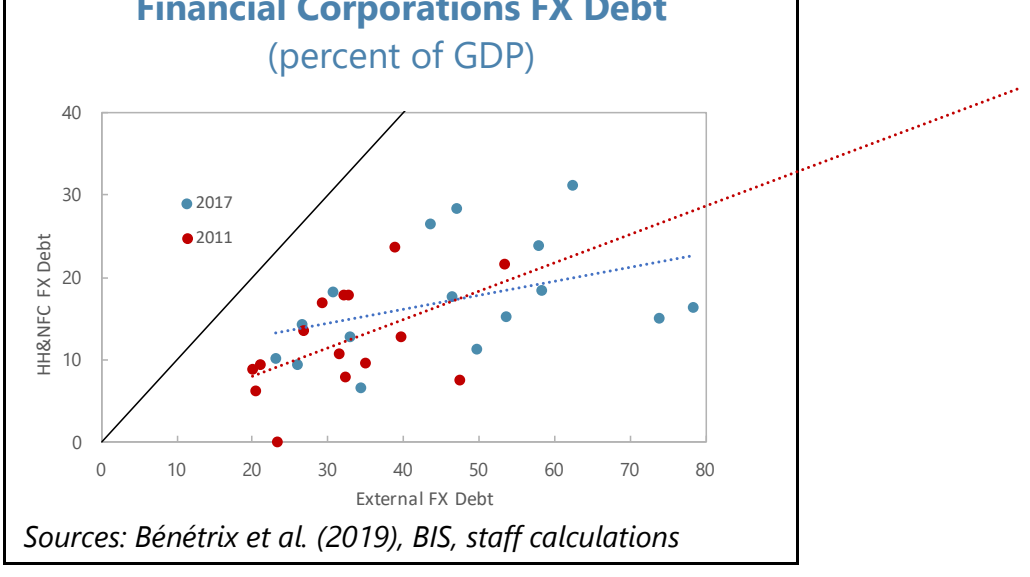
debt might reflect the impact of these factors. Nonetheless, to the extent the flexible regime is

\footnotetext{
${ }^{10}$ A more comprehensive analysis on the evolution of the FX debt of non-financial private sector was constrained by data availability. We also tried to replace external FX debt in our estimations with corporate FX debt, as aggregated using firm-level data by Kim et al. (2020), as a robustness check. The data, however, were available for only five episodes in our sample.
} 
a prerequisite for these reforms (e.g., the adoption of inflation targeting), any association between the change in the regime and FX debt would still be valid.

Fifth, the evolution of FX debt might also be affected by constraints imposed by the regulatory authority such as the tightening of macroprudential policies (MPPs). Specifically, several MPPs aimed at mitigating currency exposure were introduced over the last two decades. Most of these MPPs took the form of FX-specific reserve requirements or limits on FX positions, while direct limits on FX lending were almost non-existent before the GFC.

These MPPs could affect external FX debt in several ways, including directly via the external borrowing of banks (e.g., limits on FX positions) or indirectly through the banking sector (e.g., to the extent limits on foreign currency lending lead to lower external FX borrowing by banks). On the other hand, MPPs would not succeed in containing direct FX borrowing from abroad by the sovereign or the non-financial private sector, including in the form of capital market financing (e.g., regular issuance of bonds in international financial markets by corporates).

Our examination indicates that episodes of shifts to more flexible exchange rate regimes were rarely accompanied or followed by the tightening of FX-related MPPs such as reserve requirements differentiated by currency, limits on foreign currency lending or limits on FX positions (Figure 9). Based on our estimations, this does not alter the main regression results.

Figure 9. Tightening of FX-related MPPs

(time t: shift to more flexible ER regime)

Episodes of shifts to more flexible exchange rate regimes rarely entailed the tightening FX-related macroprudential policies.

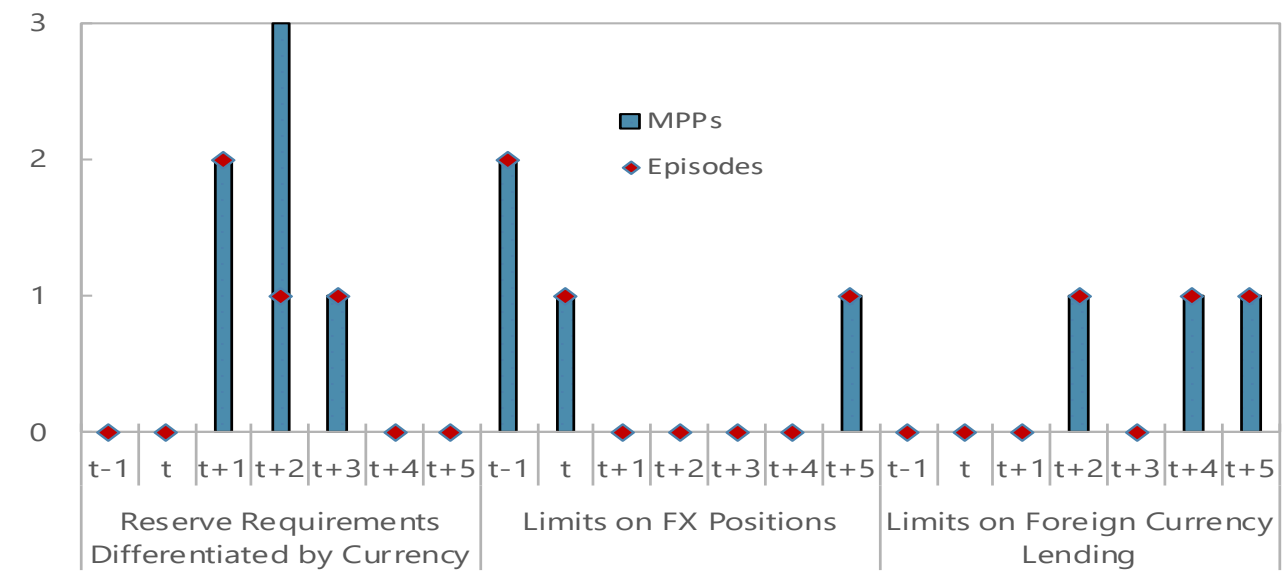

Sources: Alam et al. (2019), staff calculations

Finally, these findings should not be interpreted as a diagnosis of the overall benefits between flexible versus fixed exchange rate regimes. The paper focuses on only one aspect of the difference between the two regimes and documents lower external FX debt under flexible exchange rate regimes relative to fixed exchange rate regimes. Fixed exchange rate regimes, like flexible regimes, can be more appropriate for some countries under some circumstances ${ }^{11}$. Moreover, some degree of managing exchange rate volatility may still be

${ }^{11}$ There is a large literature on the choice of exchange rate regimes and the general considerations involved. See e.g. Bordo (2003). 
needed even in flexible exchange rate regimes. This is particularly relevant in the use of FX intervention to address disorderly market conditions and contain risks to financial stability. Specifically, the use of the policy rate to respond to external shocks could lead to a procyclical monetary policy in light of the impact of these shocks on GDP growth. By addressing disorderly market conditions, FX intervention can allow monetary policy to respond countercyclically to the domestic economy (Mano and Sgherri, 2020, and Basu et al. 2020).

\section{Conclusions}

A defining characteristic of EMs' policy challenge is managing and tempering the extent to which a decline in access to foreign financing leads to a deterioration in domestic balance sheets, firms' operations, and households' resilience ${ }^{12}$. The experience in recent decades where a tightening of global financial conditions has led to turbulence for several EMs has motivated a build-up of precautionary savings in the form of FX reserves. While this increase in policy space is widely seen as increasing policymakers' wigle roome to deal with shocks, it also introduces the possibility of greater risk taking in the private sector if the possibility of a sharp depreciation is perceived to be low.

Our findings in this paper suggest that greater exchange rate flexibility is indeed associated with lower levels of foreign currency debt. Looking initially at the summary statistics, we find a negative relationship between exchange rate flexibility and the level of FX debt in a country. Clearly, the nature of the underlying relationship could be multi-faceted and go in both directions. Our empirical analysis of the two main variables of interest suggests that a country moving towards greater exchange rate flexibility can indeed be expected to experience a decline in FX debt. While the presence of a time trend in our difference-indifference results indicates a general decline in FX debt over time, we have found a greater decline for those countries where the exchange rate went from being relatively more rigid to relatively more flexible.

These results are, however, not absolute and several caveats apply. First, the size of the effect is unlikely to be homogenous and considerations beyond the scope of this paper should be kept in mind. These include, but are not limited to, the prudential regulatory framework in each country, the composition of a country's balance of payments, the extent to which foreign debt is hedged, either naturally or with financial contracts, as well as the depth and structure of domestic financial markets and the presence of a domestic savings base. Data limitations, particularly on hedging, provide some challenges in this regard, while other issues, such as the structure of domestic markets, are better dealt with in single-country studies.

On a more general level, a reduction of exchange rate volatility by policymakers may, at the margin, alter the risk-return tradeoff by firms and households but that unintended

\footnotetext{
12 The separation between the balance sheet aspect and the operations refers to the fact that, following an external shock such as a sharpe exchange rate move, there are more than one effect at play. The balance sheet channel entails a change in the financial situation of a firm whereby the (unhedged) burden of foreign-currency debt mechanically increases following a depreciation and leads to lower net value of the firm. The operations aspect involves the cash flow, as a depreciation raises the operating costs, e.g. via higher (unhedged) foreigncurrency interest.
} 
consequence may be deemed to be outweighed by the positive of preventing excessive financial market turbulence. The extent to which the incentives discussed in this paper are affected by policy in the area of exchange rate flexibility thus only represent one consideration of many in the decision-making process. A parallel of the trade-off entailed in such cases can be made to the lender of last resort (LOLR) function of central banks, where a carefully considered policy intervention to address liquidity shortages may outweigh the negative moral hazard implications. Also, notwithstanding the benefits associated with flexible exchange rates, the use of FX intervention to address disorderly market conditions could increase monetary policy space to respond to external shocks. Furthermore, as in the LOLR case, supplementary policies can reduce these effects and thus improve the costbenefit trade-off for policy intervention. A deeper domestic investor base and development of financial markets would reduce dependency on foreign financing which is often less readily provided in domestic currency. Macroprudential policies that prevent a build-up of FX debt would be another concrete example in this area. Such complementarity of policies can yield non-trivial benefits which warrant further studies. 


\section{REFERENCES}

Adler, G., N. Lisack, and R. Mano, 2019, Unveiling the effects of foreign exchange intervention: A panel approach, Emerging Markets Review 40 (2019) 100620

Adler, G., Chang, R. Mano, and Y. Shao, 2020, Foreign Exchange Intervention: A Dataset of Public Data and Proxies, International Monetary Fund, forthcoming

Alam, Z., A. Alter, J. Eiseman, G. Gelos, H. Kang, M. Narita, E. Nier, and N. Wang, 2019, Digging Deeper - Evidence on the Effects of Macroprudential Policies from a New Database, IMF Working Paper 19/66

Albagli, E., M. Calani, M. Hadzi-Vaskov, M. Marcel, and L.A. Ricci, 2020, Comfort in Floating: Taking Stock of Twenty Years of Freely-Floating Exchange Rate in Chile, IMF Working Paper forthcoming

Basu, S., E. Boz, G. Gopinath, F. Roch, and F. Unsal, 2020, A Conceptual Model for the Integrated Policy Framework, IMF Working Paper 20/121

Bebczuk, R., A. Galindo, and U. Panizza, 2006, An Evaluation of the Contractionary Devaluation Hypothesis, Inter-American Development Bank Working Paper 582

Belochine, N., E. Crivelli, N. Geng, T. Scutaru, J. Wiegand, and Z. Zhan, 2016, Taking Stock of Monetary and Exchange Rate Regimes in Emerging Europe, European Department, International Monetary Fund

Bénétrix, A., D. Gautam, L. Juvenal, and M. Schmitz, 2019, Cross-Border Currency Exposures. New evidence based on an enhanced and updated dataset, IMF Working Paper $19 / 299$

Berkmen, S.P., and E.A. Cavallo, 2009, Exchange Rate Policy and Liability Dollarization: What Do the Data Reveal About Casuality?, IMF Working Paper 07/33

Bernanke, B.S., 2005, The Global Saving Glut and the U.S. Current Account Deficit, Homer Jones Lecture, Federal Reserve Bank of St. Louis, St. Louis, Missouri, April 14, 2005

BIS, 2013, Market volatility and foreign exchange intervention in EMEs: what has changed?, BIS Papers No 73

Blanchard, O., G. Adler, and I. de Carvalho Filho, 2015, Can Foreign Exchange Intervention Stem Exchange Rate Pressures from Global Capital Flow Shocks?, IMF Working Paper $15 / 159$

Bordo, M. D., 2003, Exchange Rate Regime Choice in Historical Perspective, IMF Working Paper 03/160

Bordo, M.D., C.M. Meissner, and D. Stuckler, 2010, Foreign currency debt, financial crises and economic growth: A long-run view, Journal of International Money and Finance 29 (2010) pp 642-665

Calvo, Guillermo A., 1998, Capital Flows and Capital-Market Crises: The Simple Economics of Sudden Stops, Journal of Applied Economics 1998 1(1), pp. 35-54.

Cowan, K., and J. De Gregorio, 2007, International Borrowing, Capital Controls, and the Exchange Rate. Lessons from Chile, In: Edwards, S. (ed.), 2007, Capital Controls and 
Capital Flows in Emerging Economies: Policies, Practices and Consequences, University of Chicago Press

Dornbusch, R., 1976, Expectations and Exchange Rate Dynamics, Journal of Political Economy, 84 (6), pp. 1161-1176.Eichengreen, B., and R. Hausmann, 1999, Exchange Rates and Financial Fragility, NBER Working Paper 7418

Eichengreen, B., R. Hausmann, and U. Panizza, 2003, The Pain of Original Sin, August 2003

Ghosh, A.R., J.D. Ostry, and M.S. Qureshi, 2014, Exchange Rate Management and Crisis Susceptibility: A Reassessment, IMF Working Paper 14/11

Ghosh, A.R., J.D. Ostry, and C. Tsangarides, 2011, Exchange Rate Regimes and the Stability of the International Monetary Fund, Occasional Paper 270, International Monetary Fund

IMF, 2003, Exchange Arrangements and Foreign Exchange Markets - Developments and Issues, International Monetary Fund, 2003

IMF, 2012, Annual Report on Exchange Arrangements and Exchange Restrictions 2012, International Monetary Fund, October 2012

IMF, 2019, Annual Report on Exchange Arrangements and Exchange Restrictions 2018, International Monetary Fund, April 2019

IMF, 2020, External Stress and the International Investment Position, Chapter 2 in the External Sector Report, International Monetary Fund, August 2020

Kamil, H., 2008, Is Central Bank Intervention Effective Under Inflation Targeting Regimes? The Case of Colombia, IMF Working Paper 08/88

Kamil, H., 2012, How Do Exchange Rate Regimes Affect Firms' Incentives to Hedge Currency Risk? Micro Evidence for Latin America, IMF Working Paper 12/69

Kim, M., R. Mano, and M. Mrkaic, 2020, Do FX interventions lead to higher FX debt? Evidence from firm-level data, forthcoming IMF Working Paper

Mano, R., and S. Sgherri, 2020, One Shock, Many Policy Responses, IMF Working Paper 20/10

Martinez, L., and A. Werner, 2002, The exchange rate regime and the currency composition of corporate debt: the Mexican experience, Journal of Development Economics 69 (2002) pp 315-334

Minsky, H., 2008, Stabilizing an Unstable Economy, McGraw-Hill Education.

Parsley, D.C., and H.A. Popper, 2006, Exchange rate pegs and foreign exchange exposure in East and South East Asia, Journal of International Money and Finance 25 (2006) pp 9921009

Patnaik, I., and Shah, A., 2010, Does the currency regime shape unhedged currency exposure?, Journal of International Money and Finance 29(5) (2010), pp 760-769.

Pratap, S., I. Lobato, and A. Somuano, 2003, Debt composition and balance sheet effects of exchange rate volatility in Mexico: a firm level analysis, Emerging Markets Review 4 (2003) pp 450-471 
Rey, H. 2015, Dilemma not Trilemma: The Global Financial Cycle and Monetary Policy Independence, NBER Working Paper No. 21162

Tapia, M., and A. Tokman, 2004, Effects of Foreign Exchange Intervention Under Public Information: The Chilean Case, Central Bank of Chile Working Papers No 255

Tong, H., and S-J. Wei, 2019, Endogenous Corporate Leverage Response to a Safer Macro Environment: The Case of Foreign Exchange Reserve Accumulation, NBER Working Paper 26545 